THE WORLD BANK ECONOMIC REVIEW, VOL, 2, NO. $1: 49-76$

\title{
Price and Income Elasticities of Demand for Modern Health Care: The Case of Infant Delivery in the Philippines
}

\author{
J. Brad Schwartz, John S. Akin, and Barry M. Popkin
}

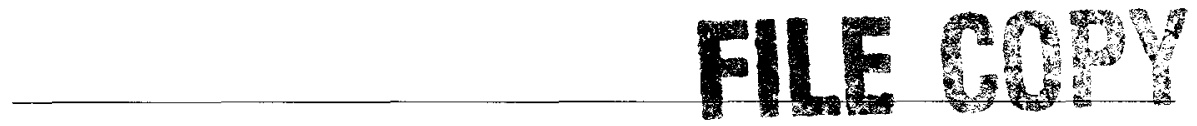

The economic determinants of the demand for infant delivery services in the Cebu region of the Philippines are examined in this article. Although user charges can be a significant source of revenues to pay for maternal and child bealth services, important policy questions are whether charging for such services will significantly deter use, and how service quality can be improved.

Price and income elasticities of the demand for types of services are computed, and simulations are carried out on the effects of different delivery service characteristics on the type of delivery method chosen.

The results suggest that increasing the availability of modern public practitioners and facilities in rural areas, increasing the hours that health care facilities are open, making drugs available, and providing trained midwives for delivery will increase the use of modern delivery services. Perhaps the most important finding-which suggests an area for further investigation-is the apparent relative insensitivity of the choice of delivery service to changes in prices and household income in our model.

In the Philippines, most births take place at home, and a significant proportion are attended either by a traditional midwife or by friends and relatives of the mother. Women continue to choose this pattern of delivery despite large investments by the health sector in modern prenatal and obstetrical health service systems. Even though a large majority of the pregnant women have direct con-

J. Brad Schwartz is currently a research economist at the Center for Population and Policy Studies, the Research Triangle Institute. He was at the University of North Carolina Population Center when this research was undertaken. John S. Akin is an economist at the University of North Carolina, Chapel Hill. He was in the former Population, Health, and Nutrition Department of the World Bank when this research was undertaken. Barry M. Popkin is an economist at the University of North Carolina at Chapel Hill and the Carolina Population Center.

Funding for this article was provided by the Population, Health, and Nutrition Department, the World Bank. The Cebu data collection effort is part of a collaborative research project between the Nutrition Center of the Philippines, the Office of Population Studies, University of San Carlos, and a group from the Carolina Population Center. Funding for the project design and data collection was provided by the Nestle's Coordinating Center for Nutrition Research, Wyeth International, the Ford Foundation, the U.S. National Academy of Science, the U.S. National Institutes of Health (contract number R1 HD19983A), and the U.S. Agency for International Development. Lionel Deang, David Fugate, and Margaret Mauney are thanked for their extensive assistance. 
tact with modern delivery services, there appears to be a preference for traditional home deliveries. It turns out that this choice can to a large extent be explained by the characteristics of the modern and traditional delivery systems and the socioeconomic characteristics of the households.

Important questions to be answered in order to make health policy decisions relate to how to provide and finance modern delivery care in low-income countries in which traditional and modern health providers coexist. The factors that affect mothers' choices of types of health care are ultimately those choices that determine whether many infants live or die or are healthy or chronically ill. We examine the determinants of the choice of type of delivery care, including economic facts (such as money prices, time prices, and household income), health facility characteristics, and delivery practitioner characteristics of both the traditional and modern delivery providers in one region of the Philippines. The sensitivity of the choice of birth delivery method to factors such as these has important implications for the placement, organization, and financing of modern delivery services. The analysis emphasizes the factors most amenable to policy change by the government of the Philippines, such as the location of clinics and the fees charged.

The data come from a survey of health facilities and delivery practitioners combined with a survey of over 3,000 women who delivered babies during 1983-84 in the Cebu region of the Philippines. In the first section below we describe the traditional and modern delivery sectors in low-income countries, in the second we present an overview of the economic model that guides the analysis, and in the third we discuss the data and provide descriptive statistics. In the fourth section we discuss the estimation technique and the results of the multivariate analysis, and in the fifth present policy implications and conclusions.

\section{BACKGROUND}

\section{The Traditional Sector}

Over two-thirds of the babies born in low-income countries are delivered by traditional birth attendants, who often are poorly educated and have no formal medical training. A national survey of traditional midwives conducted in 1974 in the Philippines found that over 50 percent had only elementary school training and most had either learned midwifery on their own or from relatives (Mangay-Angara 1981; Akin and others, 1984). It is this lack of formal medical training which differentiates traditional midwives from modern medical professionals. The modern health sector consists mainly of physicians and nurses with university educations and licensed midwives with some formal medical training.

The heavy reliance on traditional birth attendants in developing countries may be related to the heavy concentration of modern practitioners in urban areas and traditional ones in rural areas. Typically, 60 to 80 percent of the population and 70 to 90 percent of the doctors reside in urban areas (Akin and others, 1984). 
The urban facilities at which these doctors work are often inaccessible (either for geographic or economic reasons) to the lower-income and rural populations.

The traditional sector generally provides greater coverage of the rural population than does the modern sector. Whereas in Asia and Africa the modern sector usually is physically accessible to only 10 to 30 percent of the population, in many countries 100 percent of the population is within walking distance of a traditional midwife. It is not unusual for the population-per-practitioner ratio for traditional midwives to be only a fifth to a half that of modern practitioners. The traditional midwives are readily accessible to most of the population in almost all developing countries.

The work of the traditional midwives is diverse. They not only deliver babies but also assist women during the prenatal and postnatal periods and are involved in a number of important aspects of maternal and child health care. During prenatal care they often

use massage to relax muscles, relieve discomfort, and estimate the progress of pregnancy. As delivery approaches, massage is used to position the fetus. ... During labor the traditional midwife may massage the woman and administer herbal beverages. . . . At delivery many midwives help to extract the baby and the placenta. [Simpson-Hebert and others, 1980, pp. $\mathrm{J}-444-5]$.

It is generally believed that some of the practices of the traditional birth attendants are harmful, and that many others, while probably harmless, are of uncertain effect. Harmful practices, or those which can be potentially harmful, include dietary restrictions, mishandling of the umbilical cord (associated with neonatal tetanus), misuse of drugs (for example, heavy use of inappropriate antibiotics), postpartum feeding practices which exclude the feeding of colostrum, and incorrect responses to complications of pregnancy (Popkin and others 1984). Both surveys of modern medical personnel and data from hospital records repeatedly identify neonatal tetanus as the major infant mortality risk associated with deliveries attended by untrained midwives (Mangay-Angara 1981).

\section{Modern Obstetrical Care and Primary Health Care}

In the last decade there has been a major effort to expand modern health services in developing countries. One principal goal of the expansion has been the provision of inexpensive modern prenatal and delivery services. Usually, in determining the allocation of these services, the planners have concentrated on simple formulas related to geographic distribution of health services rather than on how best to provide services given the available resources and the benefits of alternative approaches.

Few studies have documented the impact of changes in health facilities and practitioners on the proportion of deliveries attended by modern practitioners, 
and even fewer have evaluated the health effects of such changes. An exception is a project in the province of Bohol, Philippines, which implemented and evaluated a maternal and child health and family planning project. Over the period of the project, the availability of low-cost modern care was found to lead to a decline from 67 percent to 1 percent in births attended by untrained midwives. Concurrent declines in the number of cases of neonatal tetanus and in the prevalence of many inappropriate delivery practices (for example, the use of bamboo slivers to cut the umbilical cord) were observed (Williamson 1982; Parado 1979). Another study found that the introduction of modern care to the area led to a reduction in fetal deaths (Akin and others 1984).

\section{The Realignment of Delivery Patterns}

In order for government investments in improved delivery services to achieve their objectives, it is essential that the determinants of the choice of type of infant delivery be considered. Surprisingly few systematic studies have considered the factors associated with the choice of delivery services-be it for modern or traditional public or private care-although several recent World Bank studies examine the broader question of demand for health services (see, for example, Dor and van der Gaag, forthcoming; Gertler, Locay, and Sanderson 1987; Dor, Gertler, and van der Gaag forthcoming; Mwabu forthcoming; and Birdsall and Chuhan 1983). Elsewhere the authors have reviewed the earlier studies and presented the results of a small case study of the factors associated with the choice of modern or traditional delivery services (Akin and others, 1984, 1986). That earlier research, based on an analysis of about five hundred births from the Bicol region of the Philippines, concluded that the choice between a modern or traditional birth attendant was made mainly on noneconomic grounds. The important explanatory variables were found to be mother's education and urban residence.

Previous studies of choice of infant delivery method, including the earlier work of these authors, have been based on small samples and, more significantly, have failed to control for some important economic and quality of service characteristics. In this study we expand on previous work by analyzing a large data set which includes information not only on the socioeconomic characteristics of the users of delivery services but also on the economic cost and service quality characteristics of all suppliers of delivery services in the community being analyzed. Moreover, because the data were collected on a prospective basis, they represent a significant improvement over those for other studies based on retrospective recall data.

\section{Economic Demand Modei.}

In this section we briefly outline a delivery service demand model which is detailed elsewhere (Akin and others, 1984, 1986). We assume that a model for analysis of delivery services must take into account the facts that delivery serv- 
ices can be provided either publicly or privately, either by untrained or trained practitioners, and either at home or away from home. In the model each type of delivery has an associated set of characteristics, including time and money prices, availability, and service quality. We assume that a woman maximizes her own well-being, which is a function of the health of her infant. The outcomes predicted as a result of this maximization process are that a woman's choice of type of delivery service will be determined by the prices, availability, and quality of the services plus a set of socioeconomic, demographic, and community factors. In general terms, the relationship between type of delivery used and the exogenous factors is as follows:

$$
Y_{i}=f\left(P_{i}, T_{i}, H_{i}, Q_{i} ; Z\right)
$$

where $Y_{i}=$ the $i^{\text {th }}$ delivery type

$i=$ at home by relatives, at home by traditional practitioners, at home by modern public practitioners, at home by modern private practitioners, away from home (at clinics or hospitals) by modern public practitioners, or away from home by modern private practitioners (six possible choices)

$P_{i}=$ cash price paid to delivery service provider of type $i$

$T_{i}=$ time price of traveling between the delivery provider of type $i$ and the woman's residence

$H_{i}=$ the hours of availability for delivery service of type $i$

$Q_{i}=$ the perceived quality of delivery service of type $i$

$Z$ = the set of household and community characteristics (such as income, assets, education, insurance coverage, residence, and household composition) affecting the income available to, the time constraints of, and the knowledge and preferences of, the mother.

\section{Survey Background}

The study site is metropolitan Cebu, an area embracing both the city of Cebu and rural areas of the Island of Cebu in the central Philippines. Metropolitan Cebu includes, besides Cebu City, coastal towns and a number of mountain villages. Although basically of Malayan stock, the metropolitan Cebu population (particularly in the urbanized areas) also contains people who are of Spanish and Chinese ancestry.

Metropolitan Cebu is composed of three administratively distinct cities (among them Cebu City, the second largest city of the country) and six other municipalities. At the time of the 1980 census, the administrative entities contained 243 barangays (the barangay is the smallest administrative unit in the Philippines and, in the rural areas, is usually identical with a village) with 171,702 households and slightly more than 1 million inhabitants. The barangay is the initial sampling unit for the survey from which the data are derived. 
Separate random samples taken from urban and rural metropolitan Cebu barangays resulted in a sample of 17 urban and 16 rural barangays.

All households in the 33 barangays were surveyed to collect data on all women who had births between May 1, 1983, and April 30, 1984. Baseline surveys were obtained during the sixth month of pregnancy for the 3,327 pregnant women who gave birth during the twelve-month period. For the analysis of delivery patterns, the sample consists of 3,075 women for whom both baseline and birth information were collected and who delivered non-twin births. Of the 3,327 baseline women, 38 ( 1.1 percent) had stillbirths, 13 (0.4 percent) had miscarriages, 26 (0.8 percent) had twin births, 135 (4.1 percent) outmigrated between the baseline and birth interviews, and 17 ( 0.5 percent) refused birth interviews. An additional 57 women in the sample communities who gave birth during the twelve-month period but either did not live in the communities during their pregnancy or were missed in the screening for pregnant women are omitted from this analysis.

The public and private health facilities serving the 33 sample barangays also were surveyed. Included in the facility sample are all facilities and personnel located in each barangay, plus personnel and facilities located outside the barangays but identified by proximity to the barangay, by legal jurisdiction over the community (for public clinics and hospitals), or by barangay informants (on questions asked during the baseline) as servicing the sample households. In total, data from 48 modern public and modern private hospitals, clinics, and health center facilities and 88 private modern and traditional health practitioners were used in this analysis. In addition, data were collected from part-time government health facilities (Barangay Health Stations, or BHSs) located in 23 of the 33 barangays.

\section{Variables}

Household income and an inventory of the resale value of all household assets were collected from each household at the time of the baseline survey. Because the baseline survey for each household occurred at different points in time over the collection period, income and assets were discounted by an appropriate price index to a common point in time at the beginning of the collection period. This adjustment ensures comparability of the value of income and assets across all households in the survey.

Delivery price data were collected from all health practitioners and facilities in the sample described above. Barangay averages were cornputed for each possible delivery option (at home by traditional practitioner, at home by modern public practitioner, at home by modern private practitioner, away from home by modern public practitioner, and away from home by modern private practitioner). In addition, households were surveyed to determine the amount of money given to relatives when they assist in delivery. In the Philippines there is a cultural norm which dictates payment for delivery in the form of a gratuity even when there is no explicit market price. Thus even relatives are paid a "fee for service" and 
Table 1. Pattern of Delivery Service Choices Made, 1983-84

\begin{tabular}{|c|c|c|c|c|c|c|}
\hline \multirow[b]{2}{*}{ Delivery type } & \multicolumn{2}{|c|}{ Urban } & \multicolumn{2}{|c|}{ Rural } & \multicolumn{2}{|c|}{ Total } \\
\hline & Number & Percent & Number & Percent & Number & Percent \\
\hline Relatives and friends, at home & 130 & 5.45 & 64 & 8.84 & 194 & 6.25 \\
\hline $\begin{array}{l}\text { Traditional practitioner, at } \\
\text { home }\end{array}$ & 511 & 21.77 & 460 & 63.54 & 971 & 31.62 \\
\hline Public practitioner, at home & 405 & 17.26 & 112 & 15.47 & 517 & 16.83 \\
\hline Private practitioner, at home & 200 & 8.48 & 14 & 1.93 & 214 & 6.94 \\
\hline $\begin{array}{l}\text { Public practitioner, away from } \\
\text { home }\end{array}$ & 508 & 21.64 & 35 & 4.83 & 543 & 17.68 \\
\hline $\begin{array}{l}\text { Private practitioner, away from } \\
\text { home } \\
\text { Total }\end{array}$ & $\begin{array}{r}597 \\
2,351\end{array}$ & $\begin{array}{r}25.40 \\
100.00\end{array}$ & $\begin{array}{r}39 \\
724\end{array}$ & $\begin{array}{r}5.39 \\
100.00\end{array}$ & $\begin{array}{r}636 \\
3,075\end{array}$ & $\begin{array}{r}20.68 \\
100.00\end{array}$ \\
\hline
\end{tabular}

barangay averages of this fee are included in our empirical specification as an expected price, to control for differences in money prices across all delivery options. The average money price by barangay for each type of delivery is used to construct a full menu of delivery prices for each household in the survey. There is fairly wide variation in the money prices paid for the different types of delivery. The price differences are notably large between home and away delivery in general, as well as between public and private away-from-home delivery.

The travel time between the mother and delivery practitioner represents the proximity of each delivery option, whether the mother chooses to travel to the practitioner or to have the practitioner travel to her home for delivery. The quantification of this variable is complex. From the location of the household we determine the facilities available for each type of delivery and from the facilities we determine their populations served. We carry out an analysis of transportation patterns, topography, and distance to estimate the travel time of each household to the relevant public, private, or traditional delivery practitioner. We do not, however, have information on the number of people accompanying the mother (for away-from-home delivery) so that even this very detailed evaluation of travel time considerations may be incomplete for some households.

The pattern of delivery choice across the six methods represented in the dependent variable is presented in table 1 . Table 2 describes each independent variable used, and table 3 shows the mean values and standard deviations of the independent variables. All variables are presented separately for urban and rural samples for reasons discussed below.

\section{Estimation Method and Results}

The complexity of the issues addressed here is reflected in the range of overlapping methodological choices available for our analysis. We have used the mixed multinomial logit technique to estimate the relationships between delivery 
Table 2. Variable Descriptions

Delivery-specific variables

Price

Travel time

Hours available

Drugs available

Untrained practitioner

Trained midwife

The average price, in pesos, for each delivery type in each barangay is used as the price facing women in each barangay.

The time, in minutes, between the household and the delivery practitioner.

The number of hours per week that the practitioner and/or facility is available.

Whether drugs are available at the public or private facility (yes $=1$; no $=0$ ).

Whether the delivery practitioner has had formal medical training (yes $=0 ;$ no $=1$ )

Whether the usual delivery practitioner at the public or private facility was a trained midwife (yes $=1$; doctors, nurses, or combinations of doctors, nurses, and midwives $=0$ ).

Individual and bousehold characteristics

Household income

Household assets

Mother's education

Father's education

Father present

Mother's age

Children under age 6

Females over age 13

Cebuano

Electricity

Insurance coverage

Wet season

Dry season

Private prenatal visit

Public prenatal visit

Traditional prenatal visit
Annual household income, in thousands of pesos.

Total value of assets, in thousands of pesos, owned by the household including, among other things, land, housing, consumer goods, and vehicles.

Years of formal schooling.

Years of formal schooling interacted with whether the father was present.

Whether the father is present in the household (yes $=1 ;$ no $=0$ ).

Age in years.

Number of children between the ages $0-6$ years.

Number of females in the household aged 13 and older.

Ethnic origin indicated by language spoken in the household (Cebuano spoken by both husband and wife $=1$; otherwise $=0$ ).

Whether the household has electricity (yes $=1$; no $=0$ ).

Whether the woman is covered by health insurance (yes $=1 ;$ no $=0$ ).

Whether the childbirth occurred during the rainy season (June-October $=1$; otherwise $=0$ ).

Whether the childbirth occurred during dry months (February-April $=1$; otherwise $=0$ ).

Whether a prenatal visit was made to a private practitioner (yes $=1$; no $=0$ ).

Whether a prenatal visit was made to a public practitioner (yes $=1$; no $=0$ ).

Whether a prenatal visit was made to a traditional practitioner (yes $=1$; no $=0$ ).

Source: Original surveys; information about the data sets is available, upon written request, from the authors. 
Table 3. Sample Means and Standard Deviations of Independent Variables

\begin{tabular}{|c|c|c|c|c|c|c|}
\hline \multirow[b]{2}{*}{ Variable } & \multicolumn{2}{|c|}{ Urban } & \multicolumn{2}{|c|}{ Rural } & \multicolumn{2}{|c|}{ All } \\
\hline & Mean & $S D^{a}$ & Mean & $S D$ & Mean & $S D$ \\
\hline \multicolumn{7}{|l|}{ DELIVERY-SPECIFIC } \\
\hline \multicolumn{7}{|l|}{ Price (in pesos) } \\
\hline Relatives & 48.66 & $(20.14)$ & 27.36 & $(8.47)$ & 43.64 & $(20.22)$ \\
\hline Traditional & 56.96 & $(15.85)$ & 48.33 & $(17.09)$ & 54.92 & $(16.56)$ \\
\hline Public, home & 51.27 & $(14.74)$ & 41.17 & $(6.62)$ & 48.89 & $(13.96)$ \\
\hline Private, home & 66.98 & $(16.11)$ & 66.37 & $(39.92)$ & 66.83 & $(23.94)$ \\
\hline Public, away & 169.80 & $(48.75)$ & 162.13 & $(70.33)$ & 167.99 & $(54.69)$ \\
\hline Private, away & 426.81 & $(104.70)$ & 378.04 & $(102.93)$ & 391.94 & $(121.84)$ \\
\hline All & 136.61 & $(28.28)$ & 120.27 & $(13.80)$ & 128.95 & $(25.40)$ \\
\hline \multicolumn{7}{|l|}{ Travel time (in minutes) ${ }^{b}$} \\
\hline Traditional & 7.27 & $(4.73)$ & 24.15 & $(21.13)$ & 11.25 & $(13.16)$ \\
\hline Public & 11.23 & $(5.66)$ & 32.51 & $(24.67)$ & 16.24 & $(15.79)$ \\
\hline Private & 4.39 & $(2.91)$ & 30.15 & $(25.16)$ & 10.46 & $(16.57)$ \\
\hline All & 6.41 & $(2.44)$ & 24.99 & $(15.21)$ & 10.78 & $(11.04)$ \\
\hline \multicolumn{7}{|l|}{ Hours available (perweek) } \\
\hline Public, away & 127.77 & $(58.06)$ & 58.74 & $(42.25)$ & 111.49 & $(62.09)$ \\
\hline Private, away & 148.95 & $(36.16)$ & 127.94 & $(42.76)$ & 143.99 & $(38.85)$ \\
\hline \multicolumn{7}{|l|}{ Drugs available } \\
\hline Public, away & 0.51 & $(0.50)$ & 0.53 & $(0.26)$ & 0.51 & $(0.49)$ \\
\hline Private, away & 0.45 & $(0.49)$ & 0.36 & $(0.42)$ & 0.43 & $(0.49)$ \\
\hline Untrained practitioners ${ }^{\mathrm{d}}$ & 0.33 & $(0.06)$ & 0.33 & $(0.06)$ & 0.33 & $(0.06)$ \\
\hline \multicolumn{7}{|l|}{ Trained midwives } \\
\hline Public, home & 0.41 & $(0.49)$ & 0.59 & $(0.49)$ & 0.44 & $(0.50)$ \\
\hline Private, home & 0.45 & $(0.50)$ & 0.43 & $(0.48)$ & 0.45 & $(0.47)$ \\
\hline Public, away & 0.32 & $(0.47)$ & 0.95 & $(0.21)$ & 0.47 & $(0.50)$ \\
\hline Private, away & 0.00 & & 0.00 & & 0.00 & \\
\hline \multicolumn{7}{|c|}{ INDIVIDUAL AND HOUSEHOLD CHARACTERISTICS } \\
\hline Household income & 0.30 & $(0.47)$ & 0.19 & $(0.27)$ & 0.28 & $(0.44)$ \\
\hline Household assets & 14.25 & $(54.42)$ & 5.76 & (19.35) & 12.25 & $(48.63)$ \\
\hline Mother's education & 7.62 & $(3.29)$ & 5.46 & $(2.29)$ & 7.11 & (3.31) \\
\hline Father's education & 7.49 & $(3.41)$ & 5.09 & $(3.01)$ & 6.93 & $(3.51)$ \\
\hline Father present & 0.94 & $(0.24)$ & 0.95 & $(0.21)$ & 0.94 & $(0.23)$ \\
\hline Mother's age & 25.88 & $(5.84)$ & 26.70 & (6.46) & 26.07 & $(6.00)$ \\
\hline Children under 6 & 1.49 & (1.14) & 1.67 & $(1,12)$ & 1.53 & $(1.14)$ \\
\hline Females over 13 & 0.51 & $(0.90)$ & 0.36 & $(0.76)$ & 0.47 & $(0.87)$ \\
\hline Cebuano & 0.91 & $(0.29)$ & 0.95 & $(0.21)$ & 0.92 & $(0.27)$ \\
\hline Electricity & 0.60 & $(0.49)$ & 0.18 & $(0.38)$ & 0.50 & $\langle 0.50\rangle$ \\
\hline Insurance & 0.12 & $(0.32)$ & 0.05 & $(0.21)$ & 0.10 & $(0.30)$ \\
\hline Wet season & 0.50 & $(0.50)$ & 0.47 & $(0.50)$ & 0.49 & $\langle 0.50\rangle$ \\
\hline Dry season & 0.18 & $(0.38)$ & 0.20 & $(0.40)$ & 0.19 & $(0.39)$ \\
\hline Private prenatal visit & 0.24 & $(0.43)$ & 0.07 & $(0.26)$ & 0.20 & $(0.40)$ \\
\hline Public prenatal visit & 0.53 & $(0.50)$ & 0.47 & $(0.50)$ & 0.52 & $(0.50)$ \\
\hline Traditional prenatal visit & 0.47 & $(0.50)$ & 0.58 & $(0.50)$ & 0.49 & $(0.50)$ \\
\hline
\end{tabular}

Note: Numbers in sample: urban, 2,351; rural, 724; all, 3,075.

a. $\mathrm{SD}=$ standard deviation.

b. Travel time for relatives assumed equal to zero.

c. Hours available per week for at-home deliveries equals 168 .

d. Sample average across all choices.

Source: Original surveys; information about the data sets is available, upon written request, from the authors. 
characteristics, mothers' characteristics, and delivery choice. The dependent variable in the delivery model is in the form of a set of unordered, mutually exclusive categories. This estimation procedure allows two types of independent (explanatory) variables to be used-conditional variables, such as the price of delivery, which differs in value for any given mother on the basis of delivery choice made; and unconditional variables, such as mother's age, which does not change as a result of the choice.

An implicit assumption of the multinomial logit (MNL) estimation technique is the "Independence of Irrelevant Alternatives" (IIA). This means that the model cannot be appropriately applied when there are different degrees of substitutability or complementarity among the various choices. In our application, it would imply that each of the six delivery choices is independent and has different characteristics. It also implies that as the value of a variable pertaining to a particular delivery method changes and mothers adjust their choices in response, the proportionate distribution of their movement between that particular delivery type and the five alternatives will be identical to the initial distribution of choices over the five alternatives.

The effect of this assumption is possibly to lessen the simulated effect of changes on some specific variable values, which may change the policy implications of the findings. For instance, an increase in drug availability in public facilities might be expected to draw women almost exclusively out of the other modern options while not reducing the use of traditional practitioners.

We do not have information to suggest that any such grouping or covariance among the alternatives exists, and further research would be required to determine if such grouping is the case (for further information on the IIA property and its appropriateness see also Domencich and McFadden 1975; McFadden, Tye, and Train 1986; and Hausman and Wise 1978). Alternatively, the HausmanMcFadden specification test for multinomial logits (1984) can be used to determine if the MNL assumptions are valid. The IIA assumptions do not apply to a nested model, and future research using this methodology may also provide interesting results. We believe, however, that the IIA assumptions are appropriate for the issues being analyzed and that any limitations of the IIA assumptions are outweighed by the model's positive attributes.

$X_{i j}$ represents a vector of values for a set of independent variables (for example, the set of prices in table 3$)$ that vary by choice $(j=1,2, \ldots, N)$ and by woman $(i=1,2, \ldots, M)$, and $Z_{i}$ represents a vector of independent variables that vary only by woman. The log of the odds of any particular choice being made (choice 1 , for example) is:

$$
\begin{array}{r}
{\left[\begin{array}{r}
\operatorname{Prob}\left(Y_{i}=j\right) \\
\operatorname{Prob}\left(Y_{i}=1\right)
\end{array}\right]=\Upsilon\left(X_{i j}-X_{i 1}\right)+\beta_{j} Z_{i j}} \\
(j=2, \ldots, N)
\end{array}
$$


where the $\Upsilon$ s represent coefficients associated with the choice-varying (conditional) independent variables. A positive value for a particular coefficient implies that an increase in the value of that variable is considered a favorable change by the individual (that is, that the corresponding independent variable has positive weight in the individual's indirect utility function), and that an increase in the value of that variable for a particular choice will make it more likely that the choice affected will be made. If the coefficient on the quality of delivery is positive, for example, this indicates that adding to the service quality at any type of provider will tend to increase the individual's likelihood of choosing to use that type of delivery service, and that because of this service quality increase the individual is able to obtain a higher level of welfare.

The $\beta_{j}$ coefficients vary by choice of delivery type. In determining the probability of woman $i$ choosing delivery type 1 , the $\beta$ s reflect the influence of the woman's personal circumstances (the $Z$ variables) on her choice of any particular $j$ delivery system. A positive value for a particular coefficient implies that as the corresponding independent variable increases, the probability that choice $j$ will be chosen increases relative to other choices. The use of choice 1 in the denominator of the equation, as the basis for comparison of other choices defining the log odds, is arbitrary. All odds ratios can be computed, and we present all comparisons in our results (tables 4, 5, and 6 below).

The estimation of this model entails solving the above equations for probabilities and setting up a likelihood function (details of the procedure can be found in Maddala 1983).

\section{Model Specification Issues}

Urban or rural residence. Because urban and rural residents could reasonably be expected to behave differently in seeking delivery services, we test for such differences. A likelihood ratio test of the null hypothesis, "no behavioral difference between urban and rural residents," is rejected at the 1 percent level of significance, indicating that the two samples do behave differently. Because of this structural difference, we stratify the sample into urban and rural subsamples, and all results are presented for both urban and rural groups.

Choice of prenatal care. The type of prenatal care chosen by the mother (traditional, public, or private practitioner) may be an important factor in the choice of delivery practitioner. It is not unlikely that the choices of prenatal care and delivery practitioner are jointly determined, however, and that the choice of prenatal care is therefore endogenous to the delivery model. A statistical procedure to correct for endogeneity is to estimate the probability that each type of prenatal care is chosen by the mother and then enter these probabilities in the delivery model as lagged (predelivery) endogenous variables. Unfortunately, this procedure is inappropriate in the multinomial logit model because the error term assumptions for the instrumental variables violate the necessary logit model error assumptions. Because no perfect answer to the endogeneity problem in the 
logit model exists, we carry out two alternative estimation procedures, each of which is consistent with a specific set of assumptions about the true model. We estimate a reduced form model, in which prenatal care type is not included as an explanatory factor, and assume the results and simulations to be appropriate if the choice of prenatal care actually is endogenous to the model. As an alternative we present estimation and simulation results for a model in which the prenatal care choice is included as an exogenous explanatory variable, a model which is appropriate if in reality the choice of prenatal care type is not jointly determined with the choice of type of delivery service. We compare the results from the two approaches.

Qualifications of delivery practitioner. For each type of delivery service, we also account for the level of training of the person providing the delivery service. We include two binary dummy variables that indicate whether (1) the actual practitioner has received little or no formal medical training (that is, relatives and traditional practitioners) and (2) whether the practitioner who normally makes the delivery is a certified trained midwife. The omitted variable implicit in the inclusion of these two categories is defined as the practitioner performing the delivery being a doctor, a nurse, or a combination (team effort) of doctors, nurses, and midwives. In the sample, the second most common provider of a modern delivery, next to a trained midwife, is a combination of practitioners.

Lack of data on some spouses. There are nearly 200 observations for which the spouse was not present in the household and no information was obtained for the spouse's education. In order to control for the presence of the spouse we have included a binary variable to indicate whether the father was present. As an additional variable, we have accounted for the father's education if he is present in the household.

Income and assets. Household income and assets may have separate influences on the choice of delivery type. Present income, which is immediately spendable, may have a different effect on delivery choice (both in statistical significance and magnitude) than accumulated assets, against which borrowing is possible. In order to control for these differences we enter income and assets separately in the estimation and provide simulation results for both income and asset changes.

While this specification does allow a more exact accounting of the "wealth" of the households, we have not determined the extent of correlation between the two variables, which if significant may bias downward the significance of each variable separately. The asset variable was not used in the calculation of the income elasticities to allow comparability with other income elasticities calculated in the standard manner (that is, excluding assets). However, exclusion of the asset variable from calculation of income elasticity may reduce the elasticity measurement.

We have also chosen not to interact the income/asset and price variables. Thus we do not address the issue of the differential impact of price changes on various income groups. This approach relies on the assumption that price elasticity is independent of income. If, however, demand for delivery services is more 
sensitive to price among lower income groups (as suggested by Gertler, Locay, and Sanderson 1987), our averaging of price effects may obscure this difference. Alternative specification of the model would be necessary to determine the extent of any difference in price elasticities among income groups.

\section{Multivariate Results}

Tables 4, 5, and 6 present the results from estimation of the mixed multinomial logit model for both the urban and rural samples. (Goodness of fit statistics for the urban and rural models are given in an appendix.) The coefficients for the conditional variables indicate how changes in each of the variables affect the household's utility (welfare), and represent the effect of these factors irrespective of the delivery choice actually made (table 4). For example, because the coefficient on price is found to be negative for both the urban and rural samples, it follows that increasing the price of any of the delivery choices will decrease the utility of the household and will decrease the probability of choosing that option for which price was increased relative to the other delivery options. The coefficients on the unconditional variables are allowed to differ for each delivery method choice (tables 5 and 6). The data indicate how a change in each of these variables affects the probability of choosing each specific type of delivery.

Money and time prices. For the urban households, an increase in the money price of delivery services is a statistically significant and negative factor in the choice of delivery. For rural mothers, price is found to have a negative influence on the choice but is not statistically significant. The negative coefficient findings

Table 4. Effect of Change in Delivery System Characteristics (Conditional Variables) on Household Welfare

\begin{tabular}{lcc}
\hline Characteristic & Urban households & Rural households \\
\hline Price & $-0.0016^{* * *}$ & -0.0002 \\
& $(-3.380)$ & $(-0.148)$ \\
Travel time & -0.0088 & $-0.0312^{* * *}$ \\
& $(-1.283)$ & $(-8.639)$ \\
Hours available & $0.0149^{* * *}$ & $0.0073^{* *}$ \\
& $(12.386)$ & $(2.048)$ \\
Drugs available & $0.2621^{* * *}$ & 0.3889 \\
& $(3.174)$ & $(0.963)$ \\
Untrained midwife & $0.8457^{* *}$ & $1.3886^{*}$ \\
& $(2.088)$ & $(1.693)$ \\
Trained midwife & $0.5035^{* * *}$ & $0.4924^{*}$ \\
& $(5.631)$ & $(1.841)$ \\
\hline
\end{tabular}

$* * *$ significant at $\alpha=0.01$.

$* *$ significant at $\alpha=0.05$.

* = significant at $\alpha=0.10$.

Note: Figures in parentheses are $t$ statistics.

Source: Original surveys; information about the data sets is available, upon written request, from the authors. 
Table 5. Urban Sample: Effect of Background Characteristics of Mothers

(Unconditional Variables) on Probability of Choice of Delivery Service Type

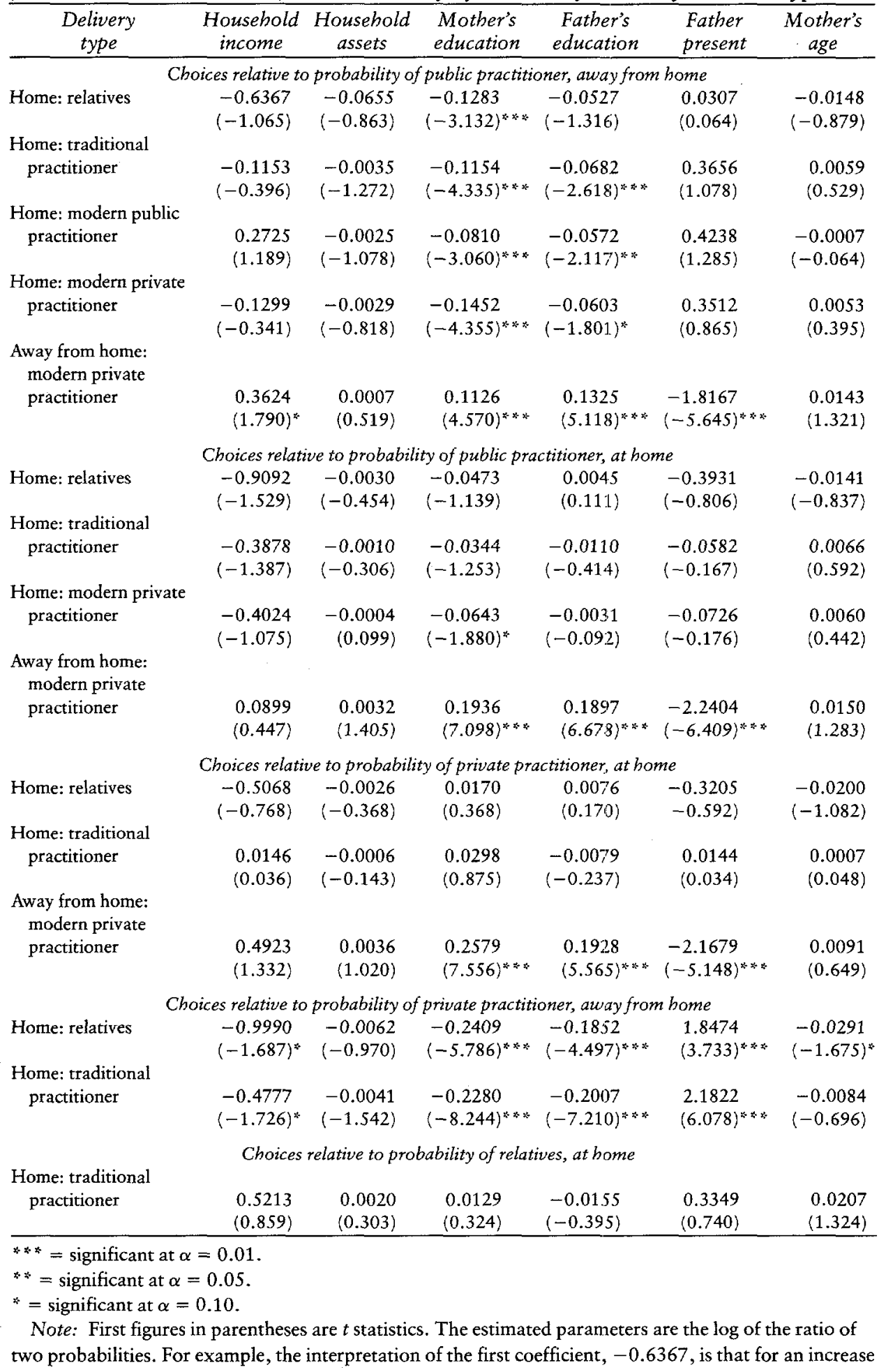




\begin{tabular}{|c|c|c|c|c|c|c|}
\hline $\begin{array}{l}\text { Children } \\
\text { under } 6\end{array}$ & $\begin{array}{l}\text { Females } \\
\text { over } 13\end{array}$ & $\begin{array}{c}\text { Cebuano } \\
\text { spoken }\end{array}$ & Electricity & Insurance & $\begin{array}{c}\text { Wet } \\
\text { season }\end{array}$ & $\begin{array}{c}\text { Dry } \\
\text { season }\end{array}$ \\
\hline \multicolumn{7}{|c|}{ Choices relative to probability of public practitioner, away from bome } \\
\hline $\begin{array}{l}0.1541 \\
(1.665)^{*}\end{array}$ & $\begin{array}{l}-0.1648 \\
(-1.112\rangle\end{array}$ & $\begin{array}{l}-0.9016 \\
(-2.663)^{*}\end{array}$ & $\begin{array}{l}-0.4383 \\
(-1.992)^{*}\end{array}$ & $\begin{array}{r}0.3579 \\
(1.012)\end{array}$ & $\begin{array}{l}-0.1650 \\
(-0.742)\end{array}$ & $\begin{array}{l}0.0335 \\
(0.112)\end{array}$ \\
\hline $\begin{array}{l}0.1155 \\
(1.912)^{*}\end{array}$ & $\begin{array}{l}-0.1150 \\
(-1.348)\end{array}$ & $\begin{array}{l}-0.5014 \\
(-1.933)^{*}\end{array}$ & $\begin{array}{l}-0.4612 \\
(-3.214)^{*}\end{array}$ & $\begin{array}{l}0.2943 \\
(1.264)\end{array}$ & $\begin{array}{l}0.0365 \\
(0.244)\end{array}$ & $\begin{array}{l}0.5099 \\
(2.638)^{* * *}\end{array}$ \\
\hline $\begin{array}{r}0.0469 \\
(0.741)\end{array}$ & $\begin{array}{r}0.0166 \\
(0.203)\end{array}$ & $\begin{array}{l}-0.3840 \\
(-1.546)\end{array}$ & $\begin{array}{l}-0.2459 \\
(-1.637)\end{array}$ & $\begin{array}{l}0.2792 \\
(1.151)\end{array}$ & $\begin{array}{r}0.0791 \\
(0.512)\end{array}$ & $\begin{array}{r}0.3152 \\
(1.540)\end{array}$ \\
\hline $\begin{array}{r}0.0895 \\
(1.160)\end{array}$ & $\begin{array}{l}-0.1921 \\
(-1.664)^{*}\end{array}$ & $\begin{array}{l}-0.7133 \\
(-2.480)^{*}\end{array}$ & $\begin{array}{r}0.2761 \\
(1.481)\end{array}$ & $\begin{array}{r}0.1312 \\
(0.418)\end{array}$ & $\begin{array}{l}-0.3880 \\
(-2.014)^{* *}\end{array}$ & $\begin{array}{l}0.3916 \\
(1.689)^{*}\end{array}$ \\
\hline $\begin{array}{l}-0.1615 \\
(-2.616)^{* \cdots *}\end{array}$ & $\begin{array}{l}0.0345 \\
(0.473)\end{array}$ & $\begin{array}{l}-0.8000 \\
(-4.159)^{* * *}\end{array}$ & $\begin{array}{l}0.6858 \\
(4.207)^{* * *}\end{array}$ & $\begin{array}{l}0.4623 \\
(2.278)^{* *}\end{array}$ & $\begin{array}{l}0.1968 \\
(1.350)\end{array}$ & $\begin{array}{l}-0.0318 \\
(-0.154)\end{array}$ \\
\hline $\begin{array}{l}0.1072 \\
(1.149)\end{array}$ & $\begin{array}{l}\text { hoices relativ } \\
-0.1813 \\
(-1.212)\end{array}$ & $\begin{array}{l}\text { oprobability of } \\
-0.5207 \\
(-1.544)\end{array}$ & $\begin{array}{l}\text { ublic practition } \\
-0.1924 \\
(-0.868)\end{array}$ & $\begin{array}{c}0.0788 \\
(0.221)\end{array}$ & $\begin{array}{l}-0.2441 \\
(-1.080)\end{array}$ & $\begin{array}{l}-0.2816 \\
(-0.945)\end{array}$ \\
\hline $\begin{array}{r}0.0686 \\
(1.114)\end{array}$ & $\begin{array}{l}-0.1316 \\
(-1.497)\end{array}$ & $\begin{array}{l}-0.1175 \\
(-0.459)\end{array}$ & $\begin{array}{l}-0.2154 \\
(-1.477)\end{array}$ & $\begin{array}{l}0.0151 \\
(0.063)\end{array}$ & $\begin{array}{l}-0.0427 \\
(-0.274)\end{array}$ & $\begin{array}{l}0.1948 \\
(1.014)\end{array}$ \\
\hline $\begin{array}{r}0.0426 \\
(0.540)\end{array}$ & $\begin{array}{l}-0.2086 \\
(-1.766)^{*}\end{array}$ & $\begin{array}{l}-0.3293 \\
\langle-1.141\rangle\end{array}$ & $\begin{array}{l}0.5220 \\
(2.771)^{* * * *}\end{array}$ & $\begin{array}{l}-0.1480 \\
(-0.462)\end{array}$ & $\begin{array}{l}-0.4672 \\
(-2.344)^{* *}\end{array}$ & $\begin{array}{r}0.0764 \\
(0.328)\end{array}$ \\
\hline $\begin{array}{l}-0.2084 \\
(-3.106)^{* * \infty}\end{array}$ & $\begin{array}{c}0.0179 \\
(0.218)\end{array}$ & $\begin{array}{l}-0.5080 \\
(-2.199)^{* *}\end{array}$ & $\begin{array}{l}0.9317 \\
(5.470)^{*+x+2}\end{array}$ & $\begin{array}{l}0.1831 \\
(0.805)\end{array}$ & $\begin{array}{r}0.1177 \\
(0.721)\end{array}$ & $\begin{array}{l}-0.3469 \\
(-1.589)\end{array}$ \\
\hline $\begin{array}{l}0.0646 \\
(0.625)\end{array}$ & $\begin{array}{c}\text { hoices relative } \\
\quad 0.0273 \\
(0.160)\end{array}$ & $\begin{array}{c}\text { probability of } \\
-0.1914 \\
(-0.525)\end{array}$ & $\begin{array}{l}\text { rivate practitio } \\
-0.7144 \\
(-2.892)^{*}\end{array}$ & $\begin{array}{c}\text { er, at bome } \\
0.2267 \\
(0.555)\end{array}$ & $\begin{array}{l}0.2231 \\
(0.878)\end{array}$ & $\begin{array}{l}-0.3580 \\
(-1.128)\end{array}$ \\
\hline $\begin{array}{r}0.0260 \\
(0.342)\end{array}$ & $\begin{array}{r}0.0770 \\
(0.643)\end{array}$ & $\begin{array}{l}0.2118 \\
(0.727)\end{array}$ & $\begin{array}{l}-0.7374 \\
(-4.044)^{* \cdots *}\end{array}$ & $\begin{array}{l}0.1631 \\
(0.525)\end{array}$ & $\begin{array}{l}0.4245 \\
(2.184)^{* * *}\end{array}$ & $\begin{array}{l}0.1184 \\
(0.534)\end{array}$ \\
\hline $\begin{array}{l}-0.2510 \\
(-3.119)^{* * *}\end{array}$ & $\begin{array}{c}0.2265 \\
(1.944)^{*}\end{array}$ & $\begin{array}{l}-0.1767 \\
(-0.663)\end{array}$ & $\begin{array}{l}0.4097 \\
(2.006)^{* *}\end{array}$ & $\begin{array}{l}0.3311 \\
(1.092)\end{array}$ & $\begin{array}{l}0.5848 \\
(2.928)^{* 0 *}\end{array}$ & $\begin{array}{l}-0.4233 \\
(-1.734)^{*}\end{array}$ \\
\hline \multicolumn{7}{|c|}{ Choices relative to probability of private practitioner, away from bome } \\
\hline $\begin{array}{l}0.3156 \\
(3.296)^{* * * *}\end{array}$ & $\begin{array}{l}-0.1992 \\
(-1.333)\end{array}$ & $\begin{array}{l}-0.0147 \\
(-0.045)\end{array}$ & $\begin{array}{l}-1.1241 \\
(-4.792)^{* \ldots *}\end{array}$ & $\begin{array}{l}-0.1044 \\
(-0.302)\end{array}$ & $\begin{array}{l}-0.3618 \\
(-1.575)\end{array}$ & $\begin{array}{r}0.0653 \\
(0.211)\end{array}$ \\
\hline $\begin{array}{l}0.2770 \\
(4.248)^{* * *}\end{array}$ & $\begin{array}{c}-0.1495 \\
(-1.706)^{*}\end{array}$ & $\begin{array}{l}0.3885 \\
(1.643)\end{array}$ & $\begin{array}{l}-1.1471 \\
(-6.932)^{* * *}\end{array}$ & $\begin{array}{l}-0.1680 \\
(-0.762)\end{array}$ & $\begin{array}{r}-0.1603 \\
(0.997)\end{array}$ & $\begin{array}{l}-0.5417 \\
(2.575)^{* * *}\end{array}$ \\
\hline \multicolumn{7}{|c|}{ Choices relative to probability of relatives, at home } \\
\hline $\begin{array}{r}-0.0386 \\
(-0.426) \\
\end{array}$ & $\begin{array}{r}0.0497 \\
(0.331) \\
\end{array}$ & $\begin{array}{r}0.4032 \\
(1.297) \\
\end{array}$ & $\begin{array}{r}-0.0230 \\
(-0.106) \\
\end{array}$ & $\begin{array}{l}-0.0636 \\
(-0.184) \\
\end{array}$ & $\begin{array}{r}0.2014 \\
(0.921) \\
\end{array}$ & $\begin{array}{l}0.4764 \\
(1.666)^{*}\end{array}$ \\
\hline
\end{tabular}

in household income, the woman would be less likely to choose at home with relatives, than away from home with a public practitioner.

Source: Original surveys; information about the data sets is available, upon written request, from the authors. 
Table 6. Rural Sample: Effect of Background Characteristics of Mothers (Unconditional Variables) on Probability of Choice of Delivery Service Type

\begin{tabular}{|c|c|c|c|c|c|c|}
\hline $\begin{array}{c}\text { Delivery } \\
\text { type }\end{array}$ & $\begin{array}{c}\text { Household } \\
\text { income }\end{array}$ & $\begin{array}{c}\text { Household } \\
\text { assets }\end{array}$ & $\begin{array}{l}\text { Mother's } \\
\text { education }\end{array}$ & $\begin{array}{c}\text { Father's } \\
\text { education }\end{array}$ & $\begin{array}{c}\text { Father } \\
\text { present }\end{array}$ & $\begin{array}{c}\text { Mother's } \\
\text { age }\end{array}$ \\
\hline \multicolumn{7}{|c|}{ Choices relative to probability of public practitioner, away from bome } \\
\hline Home: relatives & $\begin{array}{l}-4.0438 \\
(-2.512)^{*}\end{array}$ & $\begin{array}{r}-0.0011 \\
(-0.060)\end{array}$ & $\begin{array}{l}-0.3032 \\
(-3.195)^{*}\end{array}$ & $\begin{array}{c}0.0112 \\
(0.118)\end{array}$ & $\begin{array}{l}1.4149 \\
(1.388)\end{array}$ & $\begin{array}{l}-0.0578 \\
(-1.509)\end{array}$ \\
\hline $\begin{array}{l}\text { Home: traditional } \\
\text { practitioner }\end{array}$ & $\begin{array}{l}-0.3176 \\
(-0.495)\end{array}$ & $\begin{array}{l}-0.0085 \\
(-0.820)\end{array}$ & $\begin{array}{l}-0.1374 \\
(-1.795)^{*}\end{array}$ & $\begin{array}{l}-0.1290 \\
(-1.680)^{*}\end{array}$ & $\begin{array}{l}2.3200 \\
(2.770)^{*}: x\end{array}$ & $\begin{array}{l}-0.0180 \\
(-0.567)\end{array}$ \\
\hline $\begin{array}{l}\text { Home: modern pu } \\
\text { practitioner }\end{array}$ & $\begin{array}{r}-0.3655 \\
(-0.510)\end{array}$ & $\begin{array}{l}-0.0046 \\
(-0.401)\end{array}$ & $\begin{array}{l}-0.0396 \\
(-0.508)\end{array}$ & $\begin{array}{l}-0.0583 \\
(-0.718)\end{array}$ & $\begin{array}{l}1.3530 \\
(1.592)\end{array}$ & $\begin{array}{l}0.0010 \\
(0.032)\end{array}$ \\
\hline $\begin{array}{l}\text { Home: modern pr } \\
\text { practitioner }\end{array}$ & $\begin{array}{l}-1.8023 \\
(-0.723)\end{array}$ & $\begin{array}{l}0.0065 \\
(0.290\rangle\end{array}$ & $\begin{array}{r}0.1202 \\
(0.881)\end{array}$ & $\begin{array}{l}-0.0756 \\
(-0.558)\end{array}$ & $\begin{array}{l}2.7420 \\
(1.602)\end{array}$ & $\begin{array}{l}-0.1568 \\
(-2.133)^{*}\end{array}$ \\
\hline $\begin{array}{l}\text { Away from home: } \\
\text { modern private } \\
\text { practitioner }\end{array}$ & $\begin{array}{l}-0.1903 \\
(-0.282)\end{array}$ & $\begin{array}{l}0.0100 \\
(1.344)\end{array}$ & $\begin{array}{l}-0.1716 \\
(-1.863)^{*}\end{array}$ & $\begin{array}{r}0.0193 \\
(0.202)\end{array}$ & $\begin{array}{l}-0.3155 \\
(-0.313)\end{array}$ & $\begin{array}{l}0.0480 \\
(1.321)\end{array}$ \\
\hline \multicolumn{7}{|c|}{ Choices relative to probability of public practitioner, at home } \\
\hline Home: relatives & $\begin{array}{l}-3.6782 \\
(-2.315)^{* *}\end{array}$ & $\begin{array}{r}0.0034 \\
\quad(0.183)\end{array}$ & $\begin{array}{l}-0.2636 \\
(-3.459)^{*}\end{array}$ & $\begin{array}{l}0.0695 \\
(0.933)\end{array}$ & $\begin{array}{r}0.0619 \\
(0.072)\end{array}$ & $\begin{array}{l}-0.0589 \\
(-1.977)^{* *}\end{array}$ \\
\hline $\begin{array}{l}\text { Home: traditional } \\
\text { practitioner }\end{array}$ & $\begin{array}{l}0.0480 \\
(0.077)\end{array}$ & $\begin{array}{l}-0.0039 \\
(-0.351)\end{array}$ & $\begin{array}{l}-0.0978 \\
(-1.854)^{*}\end{array}$ & $\begin{array}{l}-0.0706 \\
(-1.372)\end{array}$ & $\begin{array}{r}0.9670 \\
(1.504)\end{array}$ & $\begin{array}{r}-0.01904 \\
(-0.904)\end{array}$ \\
\hline $\begin{array}{l}\text { Home: modern pr } \\
\text { practitioner }\end{array}$ & $\begin{array}{l}-1.4368 \\
(-0.579)\end{array}$ & $\begin{array}{r}0.0110 \\
(0.480)\end{array}$ & $\begin{array}{l}0.1598 \\
(1.282)\end{array}$ & $\begin{array}{l}-0.0173 \\
(-0.141)\end{array}$ & $\begin{array}{l}1.3890 \\
(0.865)\end{array}$ & $\begin{array}{l}-0.1579 \\
(-2.271)^{k *}\end{array}$ \\
\hline $\begin{array}{l}\text { Away from home: } \\
\text { modern private } \\
\text { practitioner }\end{array}$ & $\begin{array}{r}0.1752 \\
(0.238)\end{array}$ & $\begin{array}{c}0.0145 \\
(1.367)\end{array}$ & $\begin{array}{l}-0.1321 \\
(-1.792)^{*}\end{array}$ & $\begin{array}{l}0.0776 \\
(0.997)\end{array}$ & $\begin{array}{l}-1.6685 \\
(-1.965)^{* *}\end{array}$ & $\begin{array}{l}0.0469 \\
(1.672)^{*}\end{array}$ \\
\hline \multicolumn{7}{|c|}{ Choices relative to probability of private practitioner, at home } \\
\hline Home: relatives & $\begin{array}{l}-2.2414 \\
(-0.788)\end{array}$ & $\begin{array}{l}-0.0076 \\
(-0.281)\end{array}$ & $\begin{array}{l}-0.4234 \\
(-3.130)^{2}\end{array}$ & $\begin{array}{l}0.0868 \\
(0.658)\end{array}$ & $\begin{array}{l}-1.3270 \\
(-0.770)\end{array}$ & $\begin{array}{r}0.0990 \\
(1.366)\end{array}$ \\
\hline $\begin{array}{l}\text { Home: traditiona } \\
\text { practitioner }\end{array}$ & $\begin{array}{l}1.4848 \\
(0.605)\end{array}$ & $\begin{array}{l}-0.0150 \\
(-0.668)\end{array}$ & $\begin{array}{l}-0.2576 \\
(-2.098)^{* *}\end{array}$ & $\begin{array}{l}-0.0534 \\
(-0.445)\end{array}$ & $\begin{array}{r}-0.4220 \\
(-0.260)\end{array}$ & $\begin{array}{l}0.1388 \\
(2.002)^{* * *}\end{array}$ \\
\hline $\begin{array}{l}\text { Away from horne: } \\
\text { modern private } \\
\text { practitioner }\end{array}$ & $\begin{array}{r}1.6120 \\
(0.647)\end{array}$ & $\begin{array}{r}0.0035 \\
(0.159)\end{array}$ & $\begin{array}{l}-0.2918 \\
(-2.180)^{*}\end{array}$ & $\begin{array}{r}0.0948 \\
(0.711)\end{array}$ & $\begin{array}{l}-3.0575 \\
(-1.790)^{*}\end{array}$ & $\begin{array}{l}0.2048 \\
(2.860)^{* \ldots *}\end{array}$ \\
\hline \multicolumn{7}{|c|}{ Choices relative to probability of private practitioner, away from bome } \\
\hline Home: relatives & $\begin{array}{l}-3.8534 \\
(-2.391)^{*}\end{array}$ & $\begin{array}{l}-0.0111 \\
* 0.619)\end{array}$ & $\begin{array}{l}-0.1316 \\
(-1.454)\end{array}$ & $\begin{array}{l}-0.0081 \\
(-0.090)\end{array}$ & $\begin{array}{l}1.7304 \\
(1.724)^{*}\end{array}$ & $\begin{array}{l}-0.1058 \\
(-3.099)^{*}\end{array}$ \\
\hline $\begin{array}{l}\text { Home: traditiona } \\
\text { practitioner }\end{array}$ & $\begin{array}{l}-0.1272 \\
(-0.196)\end{array}$ & $\begin{array}{l}-0.0185 \\
(-1.960)^{* *}\end{array}$ & $\begin{array}{l}0.0343 \\
(0.486)\end{array}$ & $\begin{array}{l}-0.1482 \\
(-2.103)^{*}\end{array}$ & $\begin{array}{l}2.6355 \\
(3.284)^{*+*}\end{array}$ & $\begin{array}{l}-0.0660 \\
(-2.531)^{*}\end{array}$ \\
\hline \multicolumn{7}{|c|}{ Choices relative to probability of relatives, at home } \\
\hline $\begin{array}{l}\text { Home: traditiona } \\
\text { practitioner }\end{array}$ & $\begin{array}{l}3.7262 \\
(2.469)^{*}\end{array}$ & $\begin{array}{r}-0.0074 \\
+(-0.439) \\
\end{array}$ & $\begin{array}{l}0.1659 \\
(2.589)^{x \neq 2}\end{array}$ & $\begin{array}{l}-0.1401 \\
(-2.179)^{*}\end{array}$ & $\begin{array}{r}0.9051 \\
(1.240) \\
\end{array}$ & $\begin{array}{r}0.0398 \\
(1.616) \\
\end{array}$ \\
\hline
\end{tabular}




\begin{tabular}{|c|c|c|c|c|c|c|}
\hline $\begin{array}{l}\text { Children } \\
\text { under } 6\end{array}$ & $\begin{array}{l}\text { Females } \\
\text { over } 13\end{array}$ & $\begin{array}{l}\text { Cebuano } \\
\text { spoken }\end{array}$ & Electricity & Insurance & $\begin{array}{c}\text { Wet } \\
\text { season }\end{array}$ & $\begin{array}{c}\text { Dry } \\
\text { season }\end{array}$ \\
\hline \multicolumn{7}{|c|}{ Choices relative to probability of public practitioner, away from bome } \\
\hline $\begin{array}{c}0.1260 \\
(0.575)\end{array}$ & $\begin{array}{c}0.3774 \\
(1.228\rangle\end{array}$ & $\begin{array}{l}-0.2292 \\
(-0.301)\end{array}$ & $\begin{array}{c}0.4184 \\
(0.730)\end{array}$ & $\begin{array}{c}-0.3974 \\
(-0.702)\end{array}$ & $\begin{array}{r}0.0115 \\
(0.023)\end{array}$ & $\begin{array}{c}-0.3519 \\
(-0.510)\end{array}$ \\
\hline $\begin{array}{r}-0.0243 \\
(-0.130)\end{array}$ & $\begin{array}{l}0.1659 \\
(0.679)\end{array}$ & $\begin{array}{l}0.4230 \\
(0.634)\end{array}$ & $\begin{array}{l}-0.1674 \\
(-0.349)\end{array}$ & $\begin{array}{l}-0.5009 \\
(-1.125)\end{array}$ & $\begin{array}{r}-0.0503 \\
(-0.1179)\end{array}$ & $\begin{array}{l}0.2733 \\
(0.481)\end{array}$ \\
\hline $\begin{array}{r}0.0052 \\
(0.027)\end{array}$ & $\begin{array}{r}0.0264 \\
(0.105)\end{array}$ & $\begin{array}{l}0.0986 \\
(0.156)\end{array}$ & $\begin{array}{l}0.0851 \\
(0.172)\end{array}$ & $\begin{array}{l}-0.2716 \\
(-0.584)\end{array}$ & $\begin{array}{c}-0.2023 \\
(-0.450)\end{array}$ & $\begin{array}{l}-0.1991 \\
(-0.334)\end{array}$ \\
\hline $\begin{array}{c}0.2701 \\
(0.759)\end{array}$ & $\begin{array}{l}-0.5463 \\
(-0.915)\end{array}$ & $\begin{array}{l}-0.7159 \\
(-0.754)\end{array}$ & $\begin{array}{r}0.2279 \\
(0.290)\end{array}$ & $\begin{array}{l}0.9548 \\
(1.290)\end{array}$ & $\begin{array}{l}-1.1097 \\
(-1.479)\end{array}$ & $\begin{array}{l}-0.8203 \\
(-0.835)\end{array}$ \\
\hline $\begin{array}{l}-0.4792 \\
(-1.950)^{*}\end{array}$ & $\begin{array}{l}-0.3715 \\
(-1.094)\end{array}$ & $\begin{array}{c}0.0382 \\
(0.050)\end{array}$ & $\begin{array}{r}0.4726 \\
(0.817)\end{array}$ & $\begin{array}{c}0.3098 \\
(0.574)\end{array}$ & $\begin{array}{l}-0.0391 \\
(-0.072)\end{array}$ & $\begin{array}{l}0.0218 \\
(0.031)\end{array}$ \\
\hline $\begin{array}{r}0.1207 \\
(0.741\rangle\end{array}$ & $\begin{array}{c}\text { Choices relativ } \\
0.3510 \\
(1.384)\end{array}$ & $\begin{array}{l}\text { e to probabilit } \\
-0.3278 \\
(-0.546)\end{array}$ & $\begin{array}{c}\text { of public practi } \\
0.3333 \\
(0.752)\end{array}$ & $\begin{array}{c}\text { ner, at home } \\
-0.1258 \\
(-0.276)\end{array}$ & $\begin{array}{r}0.2138 \\
(0.563)\end{array}$ & $\begin{array}{l}-0.1528 \\
(-0.292)\end{array}$ \\
\hline $\begin{array}{l}-0.0296 \\
(-0.249)\end{array}$ & $\begin{array}{c}0.1395 \\
(0.804)\end{array}$ & $\begin{array}{c}0.3244 \\
(0.669)\end{array}$ & $\begin{array}{l}-0.2524 \\
(-0.786)\end{array}$ & $\begin{array}{r}-0.2293 \\
(-0.764)\end{array}$ & $\begin{array}{l}0.1520 \\
(0.551)\end{array}$ & $\begin{array}{r}0.4723 \\
(1.348)\end{array}$ \\
\hline $\begin{array}{r}0.2649 \\
\langle 0.816\rangle\end{array}$ & $\begin{array}{l}-0.5728 \\
(-1.004)\end{array}$ & $\begin{array}{l}-0.8145 \\
(-0.980)\end{array}$ & $\begin{array}{r}0.1429 \\
(0.204)\end{array}$ & $\begin{array}{l}1.2264 \\
(1.860)^{*}\end{array}$ & $\begin{array}{r}-0.9074 \\
(-1.344)\end{array}$ & $\begin{array}{c}-0.6212 \\
(-0.711)\end{array}$ \\
\hline $\begin{array}{l}-0.4845 \\
(-2.410)^{* *}\end{array}$ & $\begin{array}{r}-0.3979 \\
(-1.315)\end{array}$ & $\begin{array}{r}-0.0804 \\
(-0.096)\end{array}$ & $\begin{array}{r}0.3876 \\
(0.841)\end{array}$ & $\begin{array}{r}0.5814 \\
(1.339)\end{array}$ & $\begin{array}{l}0.1632 \\
(0.372)\end{array}$ & $\begin{array}{l}0.2209 \\
(0.403)\end{array}$ \\
\hline $\begin{array}{l}-0.1442 \\
(-0.426)\end{array}$ & $\begin{array}{c}\text { Coices relative } \\
0.9237 \\
(1.548)\end{array}$ & $\begin{array}{c}\text { to probability } \\
0.4867 \\
(0.529)\end{array}$ & $\begin{array}{c}\text { f private practi } \\
0.1904 \\
(0.252)\end{array}$ & $\begin{array}{c}\text { ner, at home } \\
-1.3521 \\
(-1.844)^{*}\end{array}$ & $\begin{array}{l}1.1212 \\
(1.577)\end{array}$ & $\begin{array}{r}0.4684 \\
(0.497)\end{array}$ \\
\hline $\begin{array}{l}-0.2944 \\
(-0.923)\end{array}$ & $\begin{array}{r}0.7123 \\
(1.253)\end{array}$ & $\begin{array}{r}1.1389 \\
\langle 1.356)\end{array}$ & $\begin{array}{l}-0.3953 \\
(-0.576)\end{array}$ & $\begin{array}{l}-1.4556 \\
(-2.256)^{6 *}\end{array}$ & $\begin{array}{l}1.0594 \\
(1.604)\end{array}$ & $\begin{array}{l}1.0935 \\
(1.276)\end{array}$ \\
\hline $\begin{array}{l}-0.7494 \\
(-2.093)^{*}\end{array}$ & $\begin{array}{r}0.1749 \\
(0.282)\end{array}$ & $\begin{array}{c}0.7541 \\
(0.797)\end{array}$ & $\begin{array}{r}0.2447 \\
(0.321)\end{array}$ & $\begin{array}{l}-0.6450 \\
(-0.893)\end{array}$ & $\begin{array}{l}1.0706 \\
(1.444)\end{array}$ & $\begin{array}{l}0.8421 \\
(0.882)\end{array}$ \\
\hline \multicolumn{7}{|c|}{ Choices relative to probability of private practitioner, away from home } \\
\hline $\begin{array}{l}0.6052 \\
(2.760)^{* * *}\end{array}$ & $\begin{array}{l}0.7489 \\
(2.165)^{*}\end{array}$ & $\begin{array}{l}-0.2674 \\
(-0.354)\end{array}$ & $\begin{array}{r}-0.0543 \\
(-0.101)\end{array}$ & $\begin{array}{r}-0.7071 \\
(-1.329)\end{array}$ & $\begin{array}{r}0.0506 \\
(0.104)\end{array}$ & $\begin{array}{l}-0.3737 \\
(-0.580)\end{array}$ \\
\hline $\begin{array}{l}0.4549 \\
(2.448)^{*}\end{array}$ & $\begin{array}{l}0.5374 \\
(1.870)^{*}\end{array}$ & $\begin{array}{l}0.3849 \\
(0.595)\end{array}$ & $\begin{array}{r}-0.6400 \\
(-1.498)\end{array}$ & $\begin{array}{l}-0.8106 \\
(-2.041)^{* *}\end{array}$ & $\begin{array}{l}-0.0112 \\
(-0.028)\end{array}$ & $\begin{array}{l}0.2514 \\
(0.500)\end{array}$ \\
\hline \multicolumn{7}{|c|}{ Choices relative to probability of relatives, at home } \\
\hline $\begin{array}{r}-0.1503 \\
(-1.091) \\
\end{array}$ & $\begin{array}{r}-0.2115 \\
(-0.965)\end{array}$ & $\begin{array}{r}0.6522 \\
(1.183)\end{array}$ & $\begin{array}{r}-0.5858 \\
(-1.454)\end{array}$ & $\begin{array}{l}-0.1035 \\
(-0.249)\end{array}$ & $\begin{array}{l}-0.0618 \\
(-0.193)\end{array}$ & $\begin{array}{l}0.6251 \\
(1.358)\end{array}$ \\
\hline
\end{tabular}

household income the woman would be less likely to choose at home with relative, than away from home with a public practitioner.

Source: Original surveys; information about the data sets is available, upon written request, from the authors. 
suggest that an increase in the user charges for any type of delivery will tend to reduce the likelihood that type will be chosen.

The relationship between travel time from the household to the delivery practitioner and the type of delivery chosen is also found to be negative for both samples but is statistically significant only for the rural sample. This finding suggests that increased distance to a facility will reduce its usage in the rural areas. Note that in this model it can't be assumed that the ratio of the time to price coefficients provides an implicit value of time for the urban and rural samples. Further work would be needed before any implications about the relative value of time between the rural and urban samples could be determined. (For a study that specifically examines the implicit value of time in health care choice, see Mwabu forthcoming.)

An explanation of the lack of statistical significance for time (distance) prices in the urban areas is that the urban sample is relatively close to all delivery options (6.41 minutes, on average) and that there is little variation in the time required to travel across all options (2.44 minutes). It appears that in these urban situations, time spent to reach a practitioner, though negatively related to delivery choice, is not an important factor in the choice. The opposite is true for the rural households who live much farther away from all types of delivery care (24.99 minutes, on average) and for whom the variation in travel time to the choices can be great. For this rural sample, time is negatively related to delivery choice and the statistical tests suggest that it is an important factor in the choice.

Hours of availability of services and availability of drugs. The hours per week that each delivery choice is available is a positive and statistically significant factor for both the urban and rural samples, indicating that an increase in its hours of availability will increase the probability that any delivery option will be chosen. Whether or not drugs are available at the public and private facilities is entered as a quality of service variable, and, as expected, is positively related to delivery choice. The availability of drugs is statistically significant for the urban sample, but we have less confidence in the finding for the rural households.

Training of practitioner. The results suggest that households prefer delivery services from midwives, whether they are formally trained or not, to deliveries performed by combinations of doctors, nurses, and midwives (the excluded category). For the delivery practitioner either to be a midwife with no formal training or a formally trained midwife is found to be positively associated with the selection of the delivery service with which that practitioner is associated, and this association is statistically significant for both the urban and rural samples.

Income, assets, and other factors. The results found for the unconditional variables (factors which do not change according to the delivery method chosen) may be interpreted as the influence of these factors on each delivery option relative to each other option. In most cases, our model finds household income and household assets not to be statistically significant factors in delivery method choice in either the urban or rural samples. In the rural sample, however, in three of the fifteen categories, having greater income or assets does appear to signifi- 
cantly increase the probability that deliveries away from home (at both public and private facilities) will be chosen.

Having insurance coverage appears to increase the probability that modern private practitioner deliveries will be chosen but to have little effect on other delivery choices. Only approximately 10 percent of the women in our sample have insurance, so the effect of price on behavior is not likely to be captured by the insurance variable in this case. It is important to note, however, that where medical insurance is more widespread, it will reduce the effective price faced by insured women. This will bias downward the measured sensitivity of delivery choice to nominal price changes. We include the dummy as a control variable to reduce any bias on the price variable caused by the few women who do have insurance coverage.

Urban mothers with a higher educational level are more inclined to choose away-from-home delivery than are their less-educated counterparts, whereas more educated rural mothers are more likely to choose modern delivery.

\section{Simulation Results}

Simulations were carried out to examine the effects of changes in the characteristics of public delivery services on the choice of home and away-from-home delivery in order to examine the policy implication of such changes. The changes examined are in travel time, money price, hours of operation, and drug availability - the factors most likely to be affected by government service provision and financing decisions. To complete the picture, the effects of changes in factors less amenable to government policy manipulation, such as household income, assets, insurance coverage, mother's education, and choice of prenatal care, are also examined.

The interpretation of the meaning of the magnitude of the coefficients in a multinomial logit model is difficult because the estimated parameters are the logarithm of the ratio of two probabilities. Table 7 presents simulations performed using the logit estimates to obtain predicted probabilities. Probabilities of choices are estimated for hypothetical households having the sample means for all independent variables, and then changes in these probabilities are determined which result from changes in the specific conditional and unconditional variables. The simulation results are revealing because the statistical significance of a relationship does not necessarily indicate that the effect of the independent variable on the dependent variable will be large. An effect could in fact be strongly significant but almost infinitely small, and therefore not "significant" in the nonstatistical sense of the word.

From the information presented in table 7 , we see that if each woman in the sample had a value for each independent variable set at its sample mean (see table 3), approximately 27 percent of the urban sample and 73 percent of the rural sample would choose to deliver at home, with either a traditional practitioner or relative attending; about 26 percent of the urban sample and 17 percent of the rural sample would choose delivery at home with a modern public or 
Table 7. Predicted Probabilities and Changes in Probabilities of Delivery Choice by Residence

\begin{tabular}{|c|c|c|c|c|c|c|c|c|c|c|c|c|}
\hline \multirow{2}{*}{$\begin{array}{c}\text { Mean values } \\
\text { and changes } \\
\text { in independent } \\
\text { variables }\end{array}$} & \multicolumn{4}{|c|}{ Urban bome } & \multicolumn{2}{|c|}{ Urban away } & \multicolumn{4}{|c|}{ Rural home } & \multicolumn{2}{|c|}{ Rural away } \\
\hline & REL & TRAD & HPUB & HPRIV & $A P U B$ & APRIV & $R E L$ & TRAD & HPUB & HPRIV & $A P U B$ & $\overline{\text { APRIV }}$ \\
\hline MEAN VALUES & 0.0553 & 0.2130 & 0.1717 & 0.0930 & 0.2124 & 0.2546 & 0.0828 & 0.6455 & 0.1573 & 0.0166 & 0.0445 & 0.0533 \\
\hline $\begin{array}{l}\text { CHANGES IN PROBABILITY } \\
\text { For price increased by one } \\
\text { standard deviation }\end{array}$ & & & & & & & & & & & & \\
\hline $\begin{array}{l}\text { Public, home }{ }^{\mathrm{a}}(51-66 \text { for } \\
\text { urban; } 41-48 \text { for rural) }\end{array}$ & 0.0003 & 0.0010 & -0.0037 & 0.0004 & 0.0011 & 0.0009 & 0.0 & 0.0002 & -0.0002 & 0.0 & 0.0 & 0.0 \\
\hline $\begin{array}{l}\text { Public, away }{ }^{\mathrm{a}}(170-218 \\
\text { for urban; } 162-232 \text { for } \\
\text { rural) }\end{array}$ & 0.0010 & 0.0042 & 0.0037 & 0.0017 & -0.0142 & 00036 & 00001 & 00007 & 00002 & 00 & $0 \cap 010$ & م \\
\hline $\begin{array}{l}\text { For travel time increased } \\
\quad \text { by one standard } \\
\text { deviation }(11-16 \text { for } \\
\text { urban; } 33-57 \text { for rural })\end{array}$ & & & & & -0.0142 & 0.0050 & 0.0001 & 0.0007 & 0.0002 & 0.0 & -0.0010 & 0.0 \\
\hline Public, home & 0.0005 & 0.0022 & -0.0078 & 0.0009 & 0.0024 & 0.0018 & 0.0071 & 0.0694 & -0.0889 & 0.0008 & 0.0079 & 0.0037 \\
\hline Public, away & 0.0004 & 0.0027 & 0.0024 & 0.0011 & -0.0090 & 0.0024 & 0.0027 & 0.0259 & 0.0074 & 0.0003 & -0.0377 & 0.0014 \\
\hline $\begin{array}{l}\text { For hours available } \\
\text { increased by one } \\
\text { standard deviation }\end{array}$ & & & & & & & & & & & & \\
\hline $\begin{array}{l}\text { Public, away (128-68 } \\
\text { hours/week for urban; } \\
60-100 \text { hours/week }\end{array}$ & & & & & & & & & & & & \\
\hline $\begin{array}{l}\text { for rural) } \\
\text { For drugs made available } \\
\text { at public facilities (from } \\
\text { 0-1) }\end{array}$ & -0.0081 & -0.0343 & -0.0304 & -0.0141 & 0.1161 & -0.0292 & -0.0016 & -0.0159 & -0.0045 & -0.0002 & 0.0231 & -0.0008 \\
\hline Public, away & -0.0034 & -0.0142 & -0.0126 & -0.0059 & 0.0482 & -0.0121 & -0.0016 & -0.0155 & -0.0045 & -0.0002 & 0.0226 & -0.0008 \\
\hline
\end{tabular}




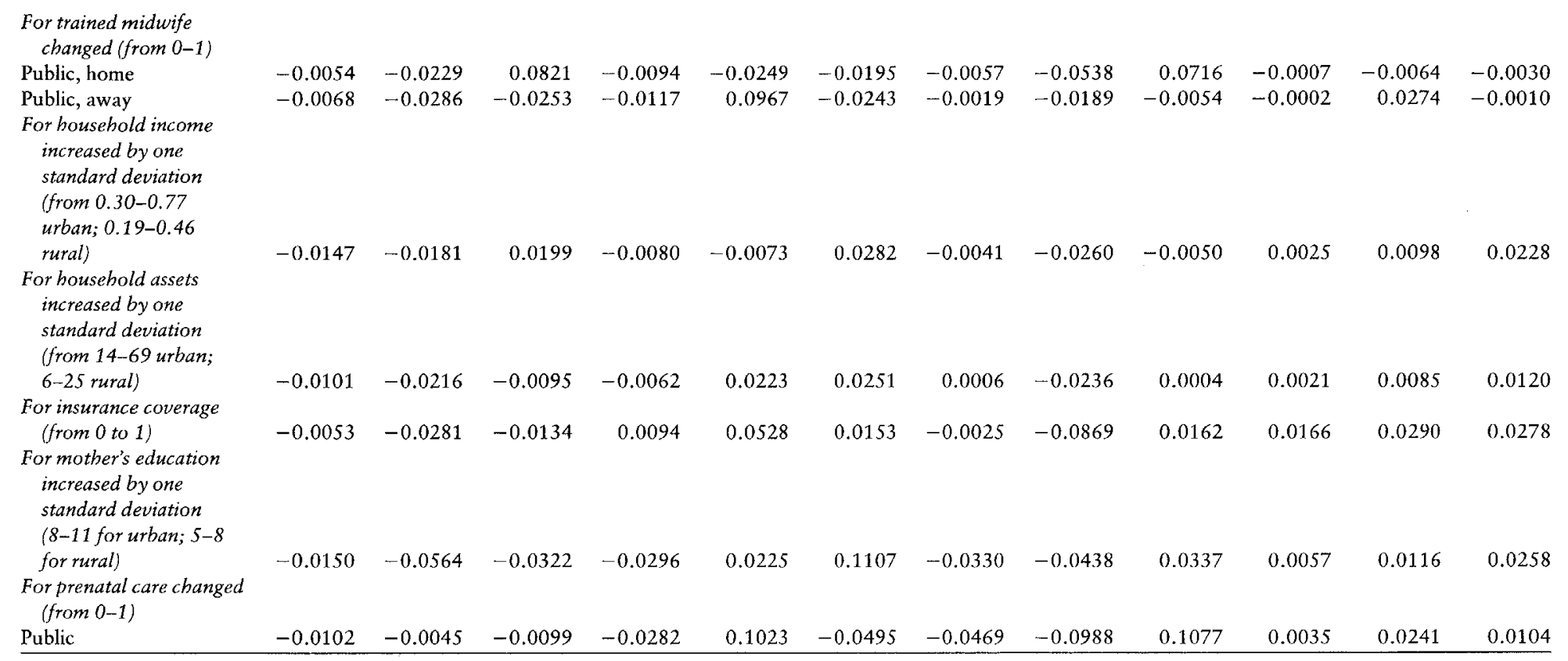

REL. = probability of home delivery with relatives

TRAD = probability of home delivery with traditional practitioner

HPUB $=$ probability of home delivery with public practitioner

HPRIV $=$ probability of home delivery with private practitioner

APUB = probability of away-from-home delivery with public practitioner

APRIV = probability of away-from-home delivery with private practitioner

a. Simulations of the effects of public prenatal care are from a separately estimated model in which prenatal care is assumed not to be jointly determined with the choice of delivery.

Source: Original surveys; information about the data sets is available, upon written request, from the authors. 
private practitioner; and 47 percent of the urban and 10 percent of the rural would choose away-from-home delivery with a modern public or private practitioner.

The simulation results, indicating expected changes in these average probabilities that result from changes in the explanatory variables, show that changes in money and time prices for public delivery services have differential impacts on women in the urban and rural samples. When the money prices of public deliveries, either at home or away, are increased by one standard deviation, the results suggest that there will be little or no change in the choices of delivery care made by the rural sample. The women in the urban sample also appear to be relatively insensitive to moderate changes in money prices, although the urban women are more responsive to changes in public delivery prices than are the rural. In the urban areas a tradeoff between traditional and public delivery is evident: increases in the price of public delivery (especially away-from-home) increase the likelihood of the choice of traditional delivery.

The simulation results for changes in the time prices of public practitioners indicate only limited responsiveness for the urban sample; the rural sample appears to be more sensitive to changes in time prices. When the travel time between a rural mother and a public practitioner for home delivery is increased by one standard deviation, the model predicts a decrease of about 0.09 in the probability that the mother will choose to use the public-practitioner-at-home option, and a 0.07 increase in her likelihood of switching to a traditional practitioner. Increasing the travel time to public facilities for away-from-home deliveries also appears greatly to decrease the probability of a rural woman choosing this option $(-0.0377)$. Note that the probability of this choice at the mean is only 0.0445 .

Often the degree of sensitivity of a dependent variable is represented by a measure called elasticity-the percentage change in the dependent variable resulting from a 1 percent change in the explanatory variable. Our results for changes in money and time prices and income are expressed as elasticities below, in order to make the comparisons more interpretable. The elasticity estimates indicate the changes in the dependent variable caused by an equal percentage change in each of the explanatory variables.

The elasticity results suggest that although many policy factors are statistically significant determinants of the choice of delivery, the choice is relatively insensitive to many of the economic determinants (money prices, time prices, and income) of demand:

\begin{tabular}{lrr} 
Money price & Urban & \multicolumn{1}{c}{ Rural } \\
Public, home & -0.0733 & -0.0074 \\
Public, away & -0.2368 & -0.0520 \\
Time price & & \\
Public, home & -0.0999 & -0.7771 \\
Public, away & -0.0932 & -1.1648 \\
Income & & \\
Public, home & 0.0739 & -0.0224 \\
Public, away & -0.0219 & 0.1550
\end{tabular}


All money price effects are found to be in the inelastic range, indicating low responsiveness of the probability of choosing a modern public practitioner for delivery to a change in the price of these practitioners. The largest of these, -0.2368 for an urban away-from-home public facility delivery, indicates that the probability of choosing this option will decrease by 0.2368 percent for a 1 percent increase in price (that is, a 1 percent change in the mean price will lead to a change in the probability that is about 0.2 percent as large as the mean probability). Our findings suggest, therefore, that a policy designed to increase the use of modern publicly provided delivery services by decreasing money prices may do little to increase demand, just as an increase in prices to raise revenues may reduce usage very little. As noted above, however, our analysis has not accounted for the differential impact of price changes among income groups. Thus, the price elasticity of demand may vary across income groups, and the results of a price increase may differ among them.

That time prices for the urban sample are also inelastic suggests that decreasing the time required to travel between public practitioners and urban expectant mothers also may have a minor effect. The elasticities of time prices for the rural sample, however, are seen to be much larger than those for the urban women, with the travel time to public facilities actually falling in the elastic range. The elasticity coefficient suggests that a 1 percent decrease in the mean travel time to modern public facilities will increase the probability of choosing that option by 1.16 percent of its mean value. It appears that locating more public practitioners and facilities in rural areas could effectively increase the use of modern delivery in these areas. Furthermore, the simulation results shown in table 6 suggest that decreasing the travel time to these modern public practitioners would lead primarily to a decrease in the use of traditional practitioners, while leaving the use of other (private) modern practitioners relatively unchanged.

Household income is found to be inelastically related to delivery method choices for both the urban and rural samples. It is interesting to note that for the urban sample, public facilities for away-from-home deliveries seem to be viewed as inferior goods in that an increase in income tends to decrease the likelihood that this delivery option will be chosen. The simulation results suggest that if they experienced income increases, mothers would substitute toward the use of private facilities and at-home deliveries with public practitioners. Conversely, for the rural sample, at-home, public-practitioner delivery seems to be viewed as an inferior good. An increase in income would tend to shift the pattern of delivery away from this public at-home option toward private at-home and both private and public away-from-home delivery.

The number of hours per week that public facilities are available is increased by 40 hours for the purpose of the simulation exercise. For the urban sample this change represents an increase to 168 hours per week (that is, 24-hour-a-day availability) and is seen to significantly increase the odds that public away-fromhome delivery will be chosen. The predicted 0.116 increase represents an increase of over 50 percent in the probability that a woman in the urban sample 
with mean characteristics would choose this option. The rural sample also appears to be very responsive to increases in the hours of availability of public facilities. When hours of operation are increased from 60 to 100 hours per week, women become 0.0231 more likely to choose this modern away-from-home option, an increase of over 50 percent of the probability predicted at mean values (table 7).

A dummy variable for whether drugs are available at the public facility is entered in the model as a proxy for the quality and range of services offered there. The simulation results indicated that adding drug availability at a public facility where drugs are not available will cause a relatively large increase in the probability that the public delivery option will be chosen. When drugs are made available the likelihood that this modern away-from-home option will be chosen is increased by 0.0482 for the urban sample, representing an increase of over 20 percent of the predicted probability when all variables are at their mean values. For the rural sample the increase is 0.0266 and represents a change of over 50 percent of the probability predicted at the mean values.

In general, both the urban and rural samples are highly responsive to having trained midwives perform deliveries either at home or at public facilities away from home. For the urban sample, having trained public midwives as the only practitioners to perform at-home deliveries would increase the probability of this option's choice by 0.0821 . For away-from-home deliveries at public facilities the result of having trained midwives as the practitioners is similar, a 0.0967 increase. For the rural sample, attendance of trained midwives in at-home public deliveries is predicted to increase the probability of the choice of at-home public delivery by 0.0716 , and for away-from-home public delivery by 0.0274 . In each of these four cases the increase in the probability of choosing the delivery option represents over 45 percent of the predicted probability at sample mean values. Also, in each case large reductions in the likelihood of selecting traditional delivery practitioners occur. It is obvious that for the Cebu samples trained midwives are highly regarded as birth attendants.

If household income is increased by one standard deviation, the model predicts that urban mothers will be more likely to choose both home deliveries by public practitioners and away-from-home deliveries at private facilities, although the magnitudes of these predicted changes are relatively small. For the rural sample an increase in household income is seen to increase the likelihood of both public and private away-from-home deliveries, as well as that of home deliveries by private practitioners.

Increases in household assets appear to increase the probability of choice of the modern away-from-home option for the urban sample, and to shift the pattern of delivery away from the traditional types of delivery for the rural sample. While the magnitudes of the simulation results suggest that changes in household wealth do not affect the pattern of delivery to a large extent, once again, inclusion of both the income and asset variables in the specification of the 
model may create some downward bias in their measured influence on delivery choice.

The results for the effect of the mother's having insurance coverage indicate that insurance increases the likelihood of choosing private at-home, public away-from-home, and private away-from-home deliveries for members of both the urban and the rural samples. In the urban sample the largest response to insurance coverage is an increase of 0.0528 in the probability of the choice of public away-from-home deliveries, a change which represents about 25 percent of the predicted probability of choosing that option at mean values for all variables. For the rural sample insurance coverage is seen to greatly increase the probability of choosing private at-home, and both public and private awayfrom-home delivery. With coverage, the probability of a home delivery with a private practitioner is doubled, and the predicted probability of public awayfrom-home deliveries is increased by 0.0290 , roughly 65 percent of the expected probability at the means. The increase in private away-from-home deliveries $(0.0278)$ represents more than 50 percent of the mean expected probability of choosing this option.

Simulations to test the effect of increases in the mother's education (increasing the number of years of education by one standard deviation) indicate that urban mothers who are more highly educated will be more likely to choose modern public and private away-from-home deliveries than will those with less education. In the rural sample, more highly educated mothers become more likely to choose modern practitioners, both at home and away-from-home, rather than relatives and traditional practitioners.

Using the coefficient results from the alternative estimations, which included dummy variables for whether the women had received prenatal care from a traditional, public, or private practitioner, simulations were performed to test the effect of the woman's choosing public prenatal care. The use of this model implies that choice of type of prenatal care is exogenous to the choice of delivery service model. For the urban sample the effect of using public prenatal care is seen to be a 0.1023 increase in the likelihood that a modern, public, away-fromhome delivery is chosen, representing nearly a 50 percent increase over the probability of this choice when all variables are at their mean values. For the rural sample choosing public prenatal care increases the probability that a modern delivery-whether away-from-home, at-home, or from public or private practitioners-will be chosen. The largest increase $(0.1077)$ is for the probability of a home delivery with a public practitioner, an increase of 68 percent over the probability at the means. The increase in the probability of choosing delivery at a public facility for those who use public prenatal care is also relatively large $(0.0241)$, representing a 54 percent increase over the probability at the means. For the rural sample the effect of using public prenatal care is to decrease the likelihood of choosing a traditional delivery by 0.0988 , a decrease of 15 percent of the probability at the mean values. For the urban sample, the largest effects of 
using public prenatal care are reductions in the probabilities of choosing both athome $(-0.028)$ and away-from-home $(-0.05)$ private practitioner delivery.

\section{Summary and Policy Implications}

The provision of modern birth delivery services has been a major concern in many low-income countries. The study reported on here examines the determinants of the choice of delivery in the Cebu region of the Philippines. The study focuses on the effects of money prices, time prices, characteristics of delivery services, and socioeconomic characteristics of the households on the choice of type of delivery care, especially modern delivery care. A unique data set, with money and time prices and facility quality measures, designed expressly for this analysis and providing prospective information for over 3,000 mother-infant pairs, is used. We examine the effect of factors which are specific to each delivery type, as well as unconditional factors which vary between households. The findings raise questions about some prior assumptions and analyses on the effect of travel time and prices of delivery, and other factors crucial for policymaking.

The results found for the travel time price of infant delivery suggest that in urban areas decreasing the travel time between expectant mothers and modern public delivery services would have a minor effect on the use of these services. In rural areas, however, decreasing the travel time between expectant mothers and modern public delivery services by locating practitioners and facilities nearby would increase the use of modern delivery services.

In addition to increasing the accessibility of public delivery practitioners and facilities in rural areas, other public policy changes, including increasing the hours of operation, increasing the availability of drugs, and providing trained midwives at public facilities are found to cause increases in the use of modern delivery services.

The results also suggest that the choice of delivery service type is relatively insensitive to changes in money prices. Thus this model suggests that policies designed to increase the use of modern publicly provided delivery services by decreasing money prices may do little to increase demand for these services. Conversely, an increase in the money price for modern publicly provided delivery services for cost recovery purposes may decrease usage very little.

Because these results run counter to some expectations, further researchmost particularly, variations in the estimation of the model-would assist in evaluating the extent to which these findings may serve to guide future policy on modern delivery services in developing countries. 


\section{Appendix: Goodness of Fit Statistics}

\begin{tabular}{|c|c|c|}
\hline \multicolumn{3}{|c|}{ Urban Sample } \\
\hline & Log likelihood & Chi-square \\
\hline $\begin{array}{l}\text { Full model ( } 66 \text { d.f.) } \\
\text { Variable excluded ( } 61 \text { d.f.) }\end{array}$ & Variable excluded (61 d.f.) & $1,596.22$ \\
\hline Household income & $-3,412.58$ & $1,585.37$ \\
\hline Household assets & $-3,410.99$ & $1,588.52$ \\
\hline Mother's education & $-3,461.19$ & $1,488.14$ \\
\hline Father's education & $-3,452.50$ & $1,519.86$ \\
\hline Father present & $-3,436.93$ & $1,536.66$ \\
\hline Mother's age & $-3,410.17$ & $1,590.17$ \\
\hline Children under 6 & $-3,419.44$ & $1,571.64$ \\
\hline Females over 13 & $-3,411.77$ & $1,586.99$ \\
\hline Cebuano & $-3,418.92$ & $1,572.67$ \\
\hline Electricity & $-3,439.09$ & $1,532.33$ \\
\hline Insurance & $-3,411.02$ & $1,588.47$ \\
\hline Wet season & $-3,413.08$ & $1,584.35$ \\
\hline Dry season & $-3,413.69$ & $1,588.13$ \\
\hline \multicolumn{3}{|c|}{ Rural Sample } \\
\hline & Log likelihood & Chi-square \\
\hline Variable excluded (61 d.f.) & & \\
\hline Household income & -670.62 & $1,181.55$ \\
\hline Household assets & -669.02 & $1,184.75$ \\
\hline Mother's education & -675.96 & $1,170.87$ \\
\hline Father's education & -670.89 & $1,181.01$ \\
\hline Father present & -673.92 & $1,173.96$ \\
\hline Mother's age & -674.52 & $1,173.76$ \\
\hline Children under 6 & -670.77 & $1,181.25$ \\
\hline Females over 13 & -669.65 & $1,183.49$ \\
\hline Cebuano & -667.35 & $1,188.10$ \\
\hline Electricity & -667.86 & $1,187.07$ \\
\hline Insurance & -699.12 & $1,196.22$ \\
\hline Wet season & -667.54 & $1,187.71$ \\
\hline Dry season & -668.17 & $1,186.46$ \\
\hline
\end{tabular}

\section{REFERENCES}

Akin, John S., C. Griffin, D. K. Guilkey, and B. M. Popkin. 1984. The Demand for Primary Health Care in the Third World (Totowa, N.J.: Littlefield, Adams).

Akin, John S., C. Griffin, D. K. Guilkey, and B. M. Popkin. 1986. "The Demand for Primary Health Services in the Bicol Region of the Philippines." Economic Development and Cultural Change 34(4):755-82.

Birdsall, Nancy, and Punam Chuhan. 1983. "Willingness to Pay for Health and Water in Rural Mali, Do wTP Questions Work?” Washington, D.C.: Population, Health, and Nutrition Department, the World Bank. Processed.

Domencich, T., and Daniel McFadden. 1975. Urban Travel Demand. Amsterdam: North-Holland.

Dor, A., P. Gertler, and J. van der Gaag. Forthcoming. "Non-Price Rationing and Medical Care Provider Choice in Rural Côte d'Ivoire." Journal of Health Economics. 
Dor, A., and J. van der Gaag. Forthcoming. "Quantity Rationing and Health Care Demand in Côte d'Ivoire." In K. Lee and A. Mills, eds., Health Economics Research in Developing Countries. New York: Oxford University Press.

Gertler, Paul, Luis Locay, and Warren Sanderson. 1987. "Are User Fees Regressive? The Welfare Implications of Health Care Financing Proposals in Peru." Journal of Econometrics 33.

Hausman, Jerry, and Daniel McFadden. 1984. "Specification Tests for the Multinomial Logit Model." Econometrica 52, no. 5 (September): 1219-40.

Hausman, Jerry, and D. Wise. 1978. "A Conditional Probit Model for Qualitative Choice: Discrete Decisions Recognizing Interdependence and Heterogeneous Preferences." Econometrica 46: 403-26.

Jimenez, Emmanuel. 1987. Pricing Policy in the Social Sectors: Cost Recovery for Education and Health in Developing Countries. Baltimore, Md.: Johns Hopkins University Press.

McFadden, Daniel, W. Tye, and K. Train. 1986. "An Application of Diagnostic Tests for the Independence from Irrelevant Alternatives Property of the Multinomial Logit Model." Transportation Research Record 637: 39-46.

Maddala, G. S. 1983. Limited Dependent and Qualitative Variables: Econometrics. Cambridge, Eng.: Cambridge University Press.

Mangay-Angara, Amansia. 1981. "Philippines: the Development and Use of the National Registry of Traditional Birth Attendants." In A. Mangay-Maglacas and H. Pizurki, eds., The Traditional Birth Attendant in Seven Countries: Case Studies in Utilization and Training, pp. 37-70. World Health Organization Public Health Paper 75. Geneva.

Mwabu, Germano M. Forthcoming. "Conditional Logit Analysis of Household Choice of Medical Treatments in Rural Villages in Kenya." Economic Development and Cultural Change.

Parado, J. P. 1979. "Experiences in the Bohol MCH/Fp Project." In Maternal and Child Health Family Planning Program: Technical Workshop Proceedings, pp. 86-99. New York: International Programs, the Population Council.

Popkin, B. M., M. E. Yamamoto, and C. C. Griffin. 1984. "Traditional and Modern Health Professionals and Breast-Feeding in the Philippines." Journal of Pediatric Gastroenterology and Nutrition 3: 765-76.

Simpson-Hebert, Mayling, Phyllis T. Piotrow, Linda J. Christie, and Janelle Streigh. May 1980. "Traditional Midwives and Family Planning." Population Reports 8, no. 22, series J, pp. J-437-48.

Williamson, N. E. 1982. "An Attempt to Reduce Infant and Child Mortality in Bohol, Philippines." Studies in Family Planning 13: 106-17. 